\title{
Eyelid Carcinoma Clinical Distant Metastasis TNM Finding v8
}

National Cancer Institute

\section{Source}

National Cancer Institute. Eyelid Carcinoma Clinical Distant Metastasis TNM Finding v8. NCI Thesaurus. Code C140472.

A clinical finding about one or more characteristics of eyelid carcinoma, following the rules of the TNM AJCC V8 classification system as they pertain to distant metastases. 